\title{
EDUCATION IN FORESTRY
}

\author{
By J. Mines Gibson \\ University of New Brunswick, Fredericton, N.B.
}

The development of forestry education in Canada followed the Canadian forestry convention of 1906 . This convention called by Sir Wilfred Laurier as the result of public interest fostered by and centered in the Canadian Forestry Association was really the beginning of Canadian forestry; and the interest developed led to the establishment of forest schools at the University of Toronto in 1907 and at the University of New Brunswick in 1908.

This movement paralleled similar development of forestry education in the United States resulting in the establishment there of eight schools of forestry between 1900 and 1905 and fourteen between 1905 and 1914.

New Brunswick is a province 70 per cent wooded, and lumbering has been its leading industry for over a century. This background pro: vided an interest and incentive in forestry and following a meeting convened in Fredericton in February, 1907, a decision was reached to estab. lish a course in scientific forestry at the University of New Brunswick.

Dr. C. C. Jones, then Chancellor of the University of New Brunswick, strongly supported this move and he was ably seconded by leading industrialists and representatives of government.

The University of New Brunswick therefore had its Department of Forestry established in 1908, and as students who had already completed two years at the University transferred to this department, the first graduates received their degrees of Bachelor of Science in Forestry in 1910.

This class of four-one of whom is in the Canadian Senate, the Honorable G. P. Burchill-mere the first group of 215 graduates who have received their training at the University of New Brunswick. Some have passed on, some have gone into other fields, but many are still in forestry and may be found in all parts of Canada, in the United States, and in the British Isles.

\section{ENTRANCE REQUIREMENTS}

The entrance requirements to the first year has been the passing of the New Brunswick Junior Matriculation examinations or equivalent examinations in Mathematics, Physics, Chemistry, English and French. Students may also be admitted to their second year if they have passed Senior Matriculation examinations in Mathematics, Physics, Chemistry, English, French or German, or equivalent examinations.

As Drawing is a required first year subject students accepted into the second year must in addition to their other courses complete the course in first year drawing. 
Junior Matriculation has been the accepted standard as New Brunswick high schools with two exceptions only prepare students as far as Junior Matriculation; and it is felt that there will be an early change in this policy.

It has been found that the first term of the first year is a period of ad. justment for the students since many are immature and since courses in high schools are not uniform because of lack of necessary facilities, particularly in science.

At the present time we have a much more mature student group, as a large percentage are ex-service men and these mature students are much more serious in their efforts. A failure with them is not only a temp. orary academic failure but in all probability makes it financially impos. sible for them to continue.

A recent analysis of tests of all new students by the Department of Psychology shows that students enrolling in forestry rank as well in these tests as the students in any other faculty.

\section{Basic Course Requirements}

From its inception it has been the policy of the school to try and give a well balanced general training in forestry based not only on a knowledge of the technical phases of forestry but also on a liberal education.

With the development of a new technique brought about by the de. velopment of applied forestry in the United States and Canada and with the development of a North American literature on forestry there is a tendency to crowd out the subjects of the liberal arts course and to fill their place with more pre-technical subjects. This is a natural evolutionary trend and the broad general phase of education can only be retained if the forestry course is lengthened.

During the early years of the course the first two years were devoted to two years of liberal arts subjects, fundamental science subjects, and pretechnical subjects in the field of engineering. For example, there were two years of English and two years of a modern language.

The pre-technical and technical courses in forestry came in the last two years. This condition was brought about by the teaching load on the staff since the school began with only one professor in forestry. It was also influenced by the need of engineering courses in forestry training when forestry and the development of the forest industry were passing through the pioneering stage.

I think it can be truly stated that the four Canadian Forest Schools have developed independently all within the same general framework but each retaining certain individual characteristics.

General policy has been influenced by the fact that there is a school forest of over 3600 acres within walking distance of the University.

This has made it possible to acquaint students with the forest and orients their training towards the so-called practical.

As the school was set up forestry was a department in Applied Science 
and a large number of engineering courses with their required mathematics was included in the early curriculum. This was in accordance with the needs of both government and industry into which the graduates were ab. sorbed.

The faculty members of the school have all received their academic training in North America with the early staff members trained at Yale and Syracuse and later staff members trained by them at the University of New Brunswick.

This evolution has also influenced course requirements. However, the school has at all times tried to keep its work and its standards at Univer. sity level and to provide the student with an opportunity of developing in. tellectually as well as technically.

\section{UNIVERSITY TRAINING AND THE INFLUENCE OF INDUSTRIAL AND GOVERNMENT REQUIREMENTS}

The influences of industrial and government requirements on University training in forestry is much more indirect than direct, that is, training has not been arranged to prepare students for examinations or tests imposed on them by either government or industry.

There has been, however, frank discussion of training by the pulp and paper industry through the Woodlands Section of the Canadian Pulp E' Paper Association and by foresters themselves through their Dominion wide professional association, the Canadian Society of Forest Engineers. The considered opinions of these groups has always been constructive and in general has been in accordance with sound educational principles.

Sometimes there are requests for men trained in a specialized technique useful in the evolution of their business and some times we at the school feel that such specialized training can more usefully be taught on the job than at the school.

Quite frequently the theory of today is the practice of tomorrow and this is just as true in forestry as in any other field.

Last year a committee of the Maritime Section of the Canadian Society of Forest Engineers reviewed our curriculum from the standpoint of the needs of industry and government.

These were the major recommendations:

1. That the Department of Forestry be made a Faculty of Forestry. This has now been instituted by the University Senate.

2. That Departments be set up within the proposed faculty of forestry headed by qualified members of the present staff and by additional members as soon as they can be obtained.

3. That two additional staff members be appointed besides the four already approved by the Senate at their February meeting.

4. That a forester be appointed as manager of the University woodlands.

5. That the substitution of a five-year course for the present four-year course be approved now for establishment in 1948 or 1949. 
6. That provision be made for granting sabbatical leave to the members of the Faculty.

7. That sufficient funds be provided for improving and adding to the equipment for teaching forestry.

These recommendations were submitted to the University Senate by the president of the Maritime Section and were well received. The first three recommendations were immediately approved and the others taken under consideration.

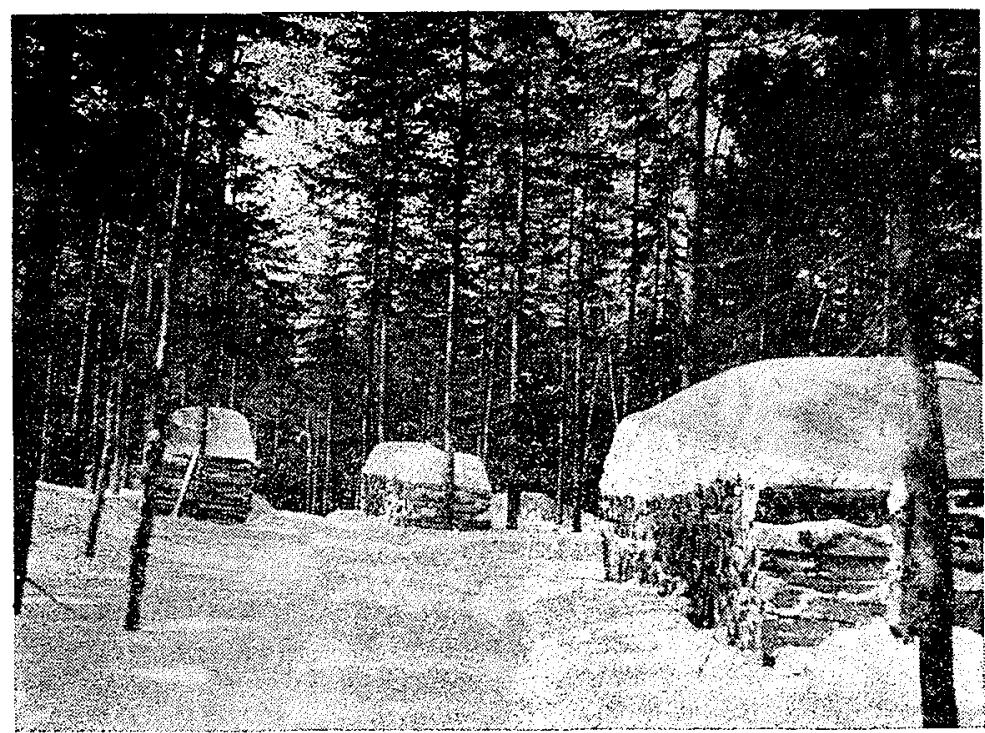

Improvement cutting. U.N.B. Lands

ENTRANCE REQUTREMENTS

I have already outlined the entrance requirements and these have and must be based on the educational facilities of the area from which most of the students originate.

Primarily our school serves the Maritime Provinces and our entrance requirements are therefore in keeping with their pre-university educational systems.

The major criticism of our pre-war students was immaturity, an immaturity that is still evident when the student graduates at the end of four years. An extra year or a five-year course will tend to correct this. A year of field work on entering or at the end of the first academic year might also be desirable and might give the student a better idea of his chosen field if the student doing this year of field work could be adequately supervised. To turn him loose to cut pulp or logs for a year might harden him physically but might tend to give him a rather confused idea of forestry. 
The present enrolment is abnormal; the pre-war enrolment followed the employment curve and did not unduly tax our facilities.

Opportunity and expected earnings play a large part in student enrol. ment and I do not think that we should attempt to be more selective in our entrance standards than engineering, science or related fields.

\section{Present Undergraduate Strength}

Canada as a nation began to recognize the value of education during the war and has through rehabilitation benefits provided thousands of young men whose studies were interrupted with an opportunity of continuing their education.

This has caused all Canadian universities to strain at the seams to meet this task.

In forestry before the war the total number of students enrolled in Canada was approximately 1 per cent of the Canadian university population; at the present time it is approximately $2 \frac{1}{2}$ per cent. At the University of New Brunswick we have attempted to give any ex-service man who is qualified an opportunity to avail himself of university facilities.

This has resulted in a present enrolment of over 400 as compared to a maximum pre-war enrolment of 75 in all four years. The peak enrolment will probably be next year with a student body in excess of 450 enrolled in Forestry.

During the war years first year classes were larger than pre-war but heavy enlistments during undergraduate years kept graduating classes small and all physically fit went into the services on graduation. These graduates have all been absorbed and while it is difficult to forecast opportunities for forestry graduates, surveys made of potential opportunities by the Canadian Society of Forest Engineers showed the following.

Shortage of foresters to fill vacancies in 1944: 280 . Number in services: 180 . Net shortage: 100 . Additional number required to carry out post-war reconstruction plans: 260. Total expected opportunities: 360 .

This estimated number of opportunities will not provide for all the students now enrolled when they graduate, but if one is to consider that a trained forester is required for every 200,000 acres-roughly 300 sq. miles -of productive forest land (there is one for every 50,000 acres in Sweden), 2500 foresters are needed in Canada and approximately 5 per cent of that number will be required for annual replacements.

Changes IN Course 1908-1946

Changes in the forestry course at the University of New Brunswick have been more in subjects and subject matter than in basic policy, and have been brought about by new techniques valuable to foresters. The tendency has also been to add more than subtract and to add more technical courses at the expense of cultural subjects.

One major change in policy took place in 1938 when alternative courses were offered. These were Forestry $A$ : emphasizing phases of forestry and 
providing training for students who are interested in the operational and administrative fields of forestry; and Forestry B, emphasizing the biological phases of Forestry and providing training for students preparing for research in forestry, forest entomology and forest pathology.

At the present time about 80 per cent of the students elect Forestry $A$ and 20 per cent Forestry B.

This trend towards specialization has proven worth while and gives students an opportunity for courses in related fields in which they are interested.

Approval has now been given by the University Senate to lengthen the course leading to a Bachelor's Degree from four to five years following Junior Matriculation.

The details of the five-year course have not yet been decided upon but it should provide an opportunity for a broader general education and in addition allow students to specialize in their fifth year.

With the many fields in which foresters find employment some degree of specialization should allow more useful training before graduation, without depriving the student of an opportunity for a more thorough education.

\section{Post Graduate Courses}

The principle of graduate studies leading to a degree of Master of Science in Forestry has been approved by the faculty of the University.

Candidates must be a Bachelor of Science in Forestry from the University of New Brunswick or some other school of recognized standing.

Specific requirements will depend on the course to be taken.

A minimum of one year's residence is required.

In addition to work in the course a thesis is required on a subject approved by the faculty.

At the present time one student is carrying out work in Forest Entomology leading to a Master's degree.

\section{INTERest OF OTHER StUdents in COURSes Given in the Faculty of Forestry}

Courses given by members of the forestry faculty are open to students of other faculties if they have completed any requisite courses preparatory to the course in which they wish to enroll.

For some years now both Arts and Science students have enrolled in courses in Entomology and Denrology and at the present time the course in Photogrammetry given in the forestry faculty is required for civil engineering students.

Arts and Science students majoring in Biology are allowed to select a course in forest entomology as an elective. 


\section{FORESTRY CHRONICLE}

General Scholastic Standing

Scholastic standing for admission to forestry has been on the same basis as that required by other departments of the University and while fewer winners of Beaverbrook scholarships enroll in Forestry than in other faculties the academic standing of forestry students is on a par with the students in the other faculties. This has shown itself where foresters have taken courses with other groups, particularly where the foresters have had the same preparatory courses.

In athletics students in forestry have carried off many honors and the faculty is well represented in all University sports. This is also true of student activities and was particularly noticeable when there were fewer forestry students in proportion to others.

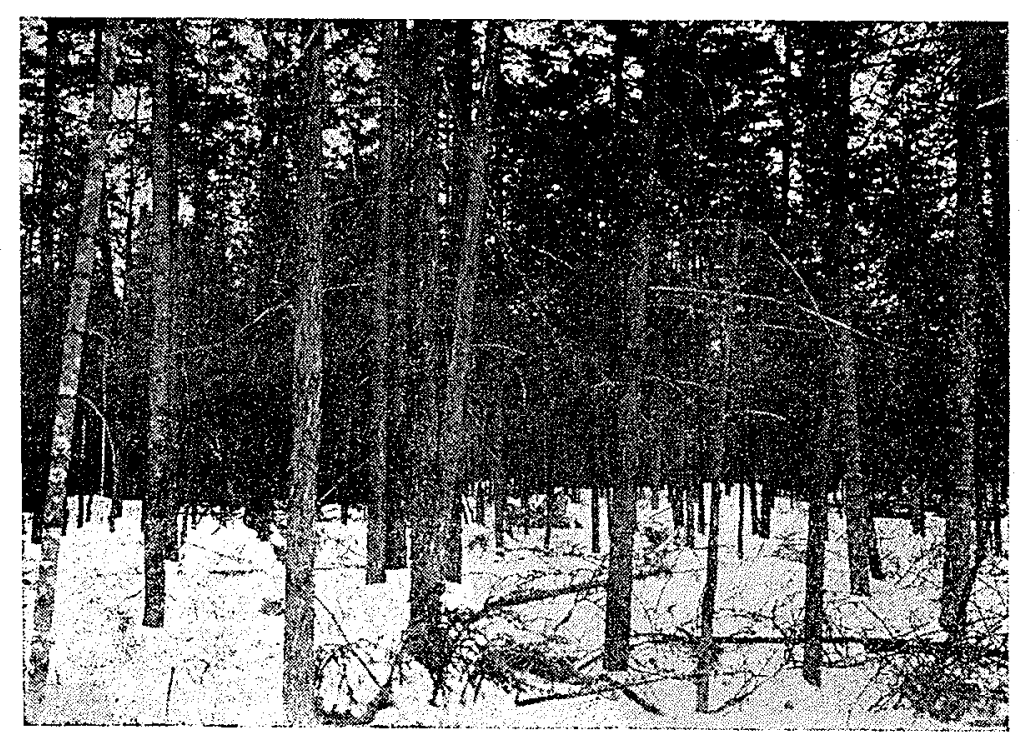

Spruce after improvement cutting. U.N.B. Lands

Number of Students Taking Graduate Work

Sixteen forestry graduates of this University have been awarded an M.Sc degree in Forestry, one an honorary LL.D. and two an honorary D.Sc. by the University of New Brunswick.

Twelve graduates have obtained Masters degrees from other universities for work in course and two have obtained degrees of Doctor of Philasophy.

Some of the Universities at which work for higher degrees was carried out are Harvard, Yale, McGill, Southern California, Duke, Michigan, and New York State College of Forestry.

At the present time six graduates are working for higher degrees, one in Canada at Toronto and five at American Universities. 


\section{POST.WAR Forestry EDUCATION}

Are we satisfied with our results in forestry education? What should we try to provide-technicians or leaders? Can you plan education to provide both? Thoughts like this continually surge through one's mind and you wonder which is most needed and how to achieve results.

Forestry in Canada has now reached a point where in some respects there are no new worlds to conquer; we know where our forests are even if we have no precise inventory and we know their general place in our economy and their present value. We have, I think, reached the end of our forest pioneering stage.

Have we trained and are we training foresters who are and will be lead. ers-foresters who understand not only forests but people, leaders who can plan and interpret our needs not only in forest planning but in guiding the thinking of our people to appreciate what our forests mean to them in jobs, wages, and homes,- - that they are renewable, that their products enter into our daily lives so frequently that we take them for granted?

Have our foresters the technical knowledge to manage our forests, to tell forest owners the way they must be cut to get the best reproduction, the amount that can be cut without impairing forest capital?

Should we try to provide specialists or should this be left to the graduate school?

Have we spread our efforts too thinly and should we concentrate on greater knowledge and intensive training with fewer courses?

Questions of this nature may intrigue you and our faculty will certainly welcome any suggestions as we are now planning a five-year course and wish it to give the soundest possible education and training to Canadian foresters. 